\title{
Distribution and Room Air Mixing Risks to Retrofitted Homes
}

A. Burdick

IBACOS, Inc. 


\section{NOTICE}

This report was prepared as an account of work sponsored by an agency of the United States government. Neither the United States government nor any agency thereof, nor any of their employees, subcontractors, or affiliated partners makes any warranty, express or implied, or assumes any legal liability or responsibility for the accuracy, completeness, or usefulness of any information, apparatus, product, or process disclosed, or represents that its use would not infringe privately owned rights. Reference herein to any specific commercial product, process, or service by trade name, trademark, manufacturer, or otherwise does not necessarily constitute or imply its endorsement, recommendation, or favoring by the United States government or any agency thereof. The views and opinions of authors expressed herein do not necessarily state or reflect those of the United States government or any agency thereof.

Available electronically at www.osti.gov/bridge

Available for a processing fee to U.S. Department of Energy and its contractors, in paper, from:

U.S. Department of Energy

Office of Scientific and Technical Information

P.O. Box 62

Oak Ridge, TN 37831-0062

phone: 865.576 .8401

fax: 865.576.5728

email: mailto:reports@adonis.osti.gov

Available for sale to the public, in paper, from:

U.S. Department of Commerce

National Technical Information Service

5285 Port Royal Road

Springfield, VA 22161

phone: 800.553 .6847

fax: 703.605.6900

email: orders@ntis.fedworld.gov

online ordering: www.ntis.gov/ordering.htm 


\title{
Distribution and Room Air Mixing Risks to Retrofitted Homes
}

\author{
Prepared for: \\ The National Renewable Energy Laboratory \\ On behalf of the U.S. Department of Energy's Building America Program \\ Office of Energy Efficiency and Renewable Energy \\ 15013 Denver West Parkway \\ Golden, CO 80401 \\ NREL Contract No. DE-AC36-08GO28308 \\ Prepared by: \\ A. Burdick \\ IBACOS, Inc. \\ 2214 Liberty Avenue \\ Pittsburgh, PA 15222 \\ NREL Technical Monitor: Stacey Rothgeb \\ Prepared under Subcontract No. KNDJ-0-40341-04
}

December 2014

iii 
The work presented in this report does not represent performance of any product relative to regulated minimum efficiency requirements.

The laboratory and/or field sites used for this work are not certified rating test facilities. The conditions and methods under which products were characterized for this work differ from standard rating conditions, as described.

Because the methods and conditions differ, the reported results are not comparable to rated product performance and should only be used to estimate performance under the measured conditions. 


\section{Contents}

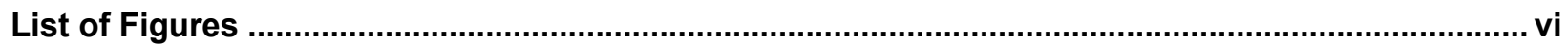

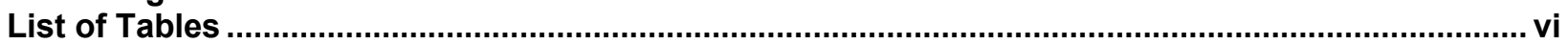

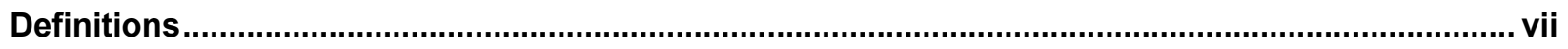

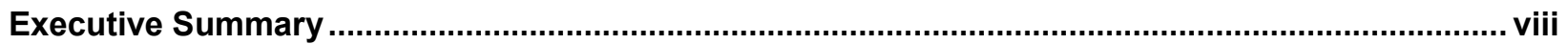

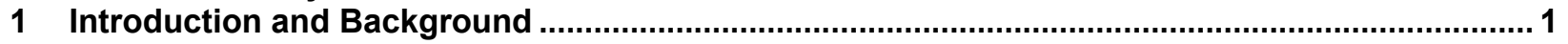

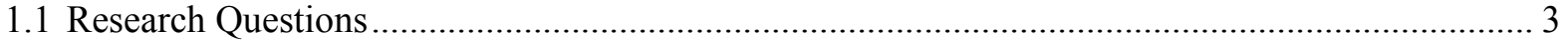

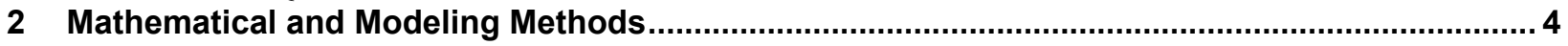

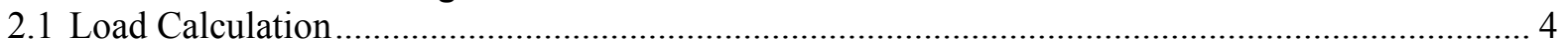

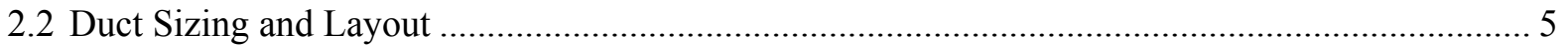

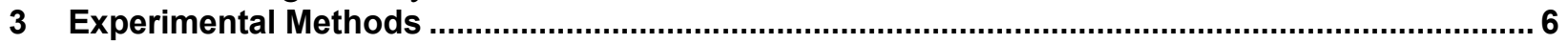

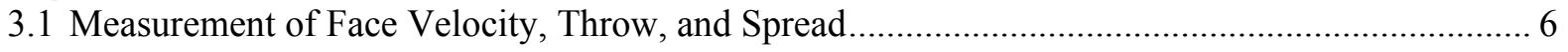

3.2 Measurements to Identify Potential Issues............................................................................. 9

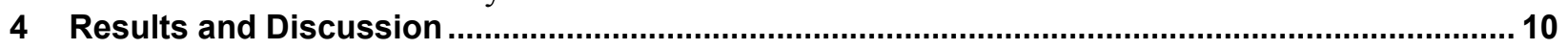

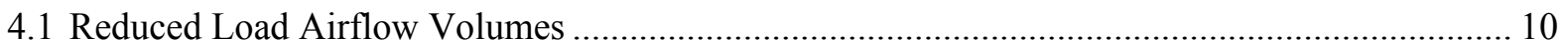

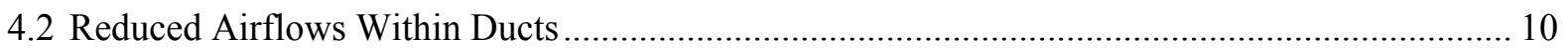

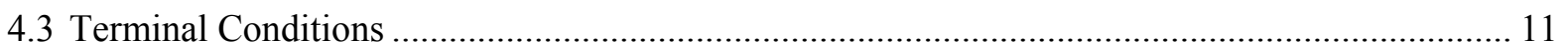

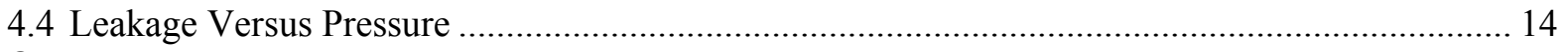

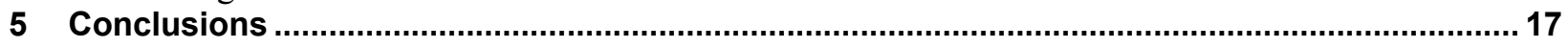

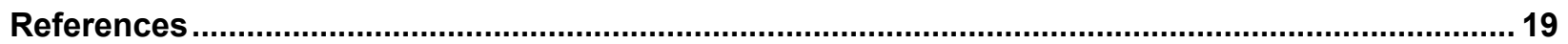




\section{List of Figures}

Figure 1. Two-story floor plan. 4

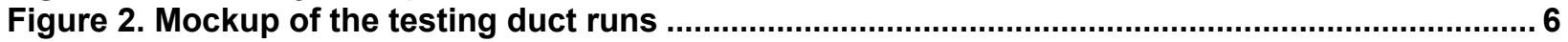

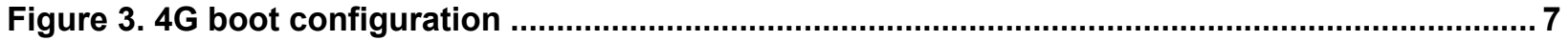

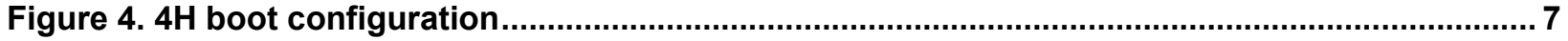

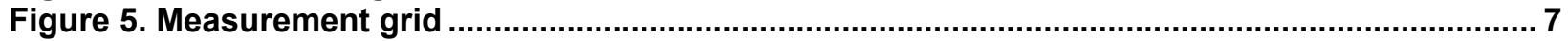

Figure 6. 4G boot configurations with the $4 \times 10$ floor register: (A) $100 \%$ open; (B) farthest from the duct, $50 \%$ open; (C) nearest to the duct, $50 \%$ open; (D) middle, $50 \%$ open ................. 8

Figure 7. 4H boot configurations with the $4 \times 10$ floor register: (A) $100 \%$ open; (B) farthest from the duct, $50 \%$ open; (C) nearest to the duct, $50 \%$ open; (D) middle, $50 \%$ open .................. 8

Figure 8. Air profiles of an unrestricted $4 \times 10$ floor register in two boot configurations (4G and $4 \mathrm{H}$ ).

Figure 9. Reduced flow profiles through an open and restricted $4 \times 10$ register with different restriction strategies for the 4G boot configuration: (A) $100 \%$ open; (B) farthest from the duct, $50 \%$ open; (C) nearest to the duct, $50 \%$ open; (D) middle, $50 \%$ open

Figure 10. Reduced flow profiles through an open and restricted $4 \times 10$ register with different restriction strategies for the $4 \mathrm{H}$ boot configuration: (A) $100 \%$ open; (B) farthest from

the duct, $\mathbf{5 0 \%}$ open; (C) nearest to the duct, $\mathbf{5 0 \%}$ open; (D) middle, $50 \%$ open ...

Figure 11. Duct leakage versus pressure ................................................................................... 15

Figure 12. Duct static pressure versus duct airflow rate for different register restrictions and duct leakage

Unless otherwise noted, all figures and photos were created by IBACOS.

\section{List of Tables}

Table 1. Number of Homes With Furnaces in Cold or Very Cold Climates, by Fuel Type* ............... 3

Table 2. Pre- and Post-Retrofit Specifications ..................................................................................... 4

Table 3. Loads and Airflows for Pre- and Post-Retrofit ................................................................ 10

Table 4. Airflows and Velocities for Pre- and Post-Retrofit ............................................................. 11

Unless otherwise noted, all tables were created by IBACOS. 


\section{Definitions}

ACCA

$\mathrm{ACH}$

$\mathrm{cfm}$

$\mathrm{ft} / \mathrm{min}$

HVAC

NYSERDA

$\mathrm{Pa}$

RECS

SHGC
Air Conditioning Contractors of America

Air changes per hour

Cubic feet per minute

Feet per minute

Heating, ventilation, and air conditioning

New York State Energy Research and Development Authority

Pascals

Residential Energy Consumption Survey

Solar heat gain coefficient 


\section{Executive Summary}

An energy efficiency upgrade reduces a home's heating and cooling load. If the load reduction is great enough and the heating, ventilation, and air conditioning system warrants replacement, that system is often upgraded with a more efficient, lower capacity system that meets the load of the upgraded house. For a single-story house with floor supply air diffusers, the ducts often are removed and upgraded. For houses with ducts that are embedded in walls, the cost of demolition precludes the replacement of ducts. The challenge with the use of existing ducts is that the reduced airflow creates a decreased throw at the supply registers, and the supply air and room air do not mix well, leading to potential thermal comfort complaints. This project investigates this retrofit scenario. The issues and solutions discussed here are relevant to all climate zones, with emphasis on climates that require cooling.

In this project, IBACOS performed load calculations for a two-story 1960s house and characterized duct sizes and layouts based on industry "rules of thumb" (Herk et al. 2014). The team performed duct-sizing calculations for unaltered ducts and post-retrofit airflows and examined airflow velocities and pressure changes with respect to various factors. The team then used a mocked-up duct and register setup to measure the characteristics of isothermal air-to reduce the effects of buoyancy from the observations - passing through the duct and leaving the register.

The reduced airflows through the original large registers significantly reduced the throw and spread of the delivered air. By reducing the net free area of the register by $50 \%$, the team observed increases in throws and spreads. With airflow of $50 \mathrm{cfm}$, reducing the net free area by $50 \%$ increased the face velocity to an acceptable range. The throws and spreads of the restricted register configuration thus improved.

The impact to duct leakage by restricting the register to increase throw and spread also was investigated with the mocked-up duct system to simulate normal leakage and a duct with a 2-in. hole. The increased leakage due to the 2 -in. hole is approximately $20 \mathrm{cfm}$ at $25 \mathrm{~Pa}$. The duct system was operated over a range of flow rates, and the duct static pressure was recorded for the duct without a hole and for the duct with a 2 -in. hole. The ducts with a 2 -in. hole had less pressure than those without. Also, at $100 \mathrm{cfm}$, the 50\% restriction resulted in an increase of $13 \mathrm{~Pa}$ for the ducts with no hole; for the ducts with a 2 -in. hole, the restriction increased the static pressure $7 \mathrm{~Pa}$. 


\section{Introduction and Background}

Occupant comfort is the overall objective of the forced-air heating, ventilation, and air conditioning (HVAC) system, and air distribution is the means of delivering conditioned air to provide occupant comfort in a room. Several current standards offer guidance and criteria on air distribution and occupant comfort in buildings and describe how those standards relate to homes. ASHRAE Standard 55 provides criteria for overall comfort and localized discomfort, including stratification $^{1}$ (ASHRAE 2010). Air Conditioning Contractors of America (ACCA) Manual T offers guidance on air distribution basics (Rutkowski 2009b). ACCA Manual RS uses a wholehouse approach of designing for occupant comfort (Rutkowski 1997), and ACCA Manual D provides specific guidelines for residential duct design (Rutkowski 2009a). The main comfort criteria related to the air distribution system are temperature mixing and uniformity, avoidance of drafts that can be created by the supply outlets, and system noise (Rutkowski 1997, 2009b).

Energy upgrades that reduce heating and cooling loads may reduce airflows in a home when the HVAC system is upgraded with a more energy-efficient, lower capacity system. IBACOS found that the basic retrofit efforts performed on retrofit unoccupied test houses in Fresno, California (Stecher and Poerschke 2014), and Round Hill, Virginia (Kampert et al. 2012), reduced cooling loads by approximately 50\%. This also was the case for heating and cooling loads with deep energy retrofits on houses IBACOS studied in conjunction with the New York State Energy Research and Development Authority (NYSERDA) (Herk et al. 2014).

Given that a home energy upgrade to the shell of a house is completed and that the load is reduced $50 \%$, the new HVAC system airflow requirement will be reduced by $50 \%$. This reduction in system airflow could cause comfort problems in the home from inadequate terminal conditions for airflow, throw, ${ }^{2}$ and supply with poor room air mixing.

The primary reason that ducts and registers are not replaced is cost - duct replacement is expensive. Likewise, utility rebate modeling does not show significant energy savings from duct replacement. Return on investment is the driving factor of many home energy upgrade programs, and the expense of total duct replacement is difficult to justify (GreenHomes America 2013). If the existing ductwork and registers are retained in the retrofitted house, the volumetric flow rate correspondingly would be reduced by $50 \%$, with corresponding velocity reductions.

The purpose of this investigation is to determine under what conditions a supply air delivery problem could potentially occur and to evaluate the feasibility of modifying the duct systems using minimally invasive strategies to improve air distribution effectiveness. Research was needed to evaluate two concerns: (1) at what level of space conditioning airflow reduction does the supply outlet throw become a potential thermal comfort issue, and (2) in what conditions is an engineering solution needed. Although an adequate return strategy also is important to system performance, this study assumes the existing return and the upgraded system with reduced airflow are adequately sized.

\footnotetext{
${ }^{1}$ Stratification is the layering of differing air temperatures in a room, where the air is cooler toward the floor and warmer near the ceiling.

${ }^{2}$ Throw is the distance that an air stream travels from an outlet at a specific terminal velocity.
} 
ASHRAE Fundamentals, Section 33.16 (ASHRAE 2009), states, "Higher supply velocities produce better room air diffusion than lower velocities, but velocity is not critical in selecting these units for heating." The second half of that statement - that velocity is not critical — is sometimes used in defense of ignoring supply outlet selection. Section 33.16 of ASHRAE Fundamentals is based on Straub (1956), along with the work of Straub and Chen (1957), using relatively large volumes of air and only for heating mode. Even in cold climates, houses have a mixed load where the cooling load airflows dominate the duct design sizing (Herk et al. 2014).

According to ACCA Manual D, residential duct systems have a direct and significant impact on occupant comfort and homeowner satisfaction (Rutkowski 2009a). To maintain a uniform temperature and to avoid stratification, the supply air also must mix adequately with the air in the room. Mixing of air within the room is a function of both the supply outlet and the shape of the airstream entering the room. As velocities increase in duct systems, so does the noise level. Ducts are sized to maintain the maximum velocity of air without adding noise to the room. ACCA Manual D further cautions that while most practitioners appreciate supply air paths and flows, some underestimate the importance of supply air outlets (Rutkowski 2009a).

Furthermore, according to ACCA Manual T, the selection and sizing of supply air outlets are as important to a successful design as making load calculations, selecting equipment, or sizing ducts. Supply air outlets must mix the raw supply air with the room air without creating drafts or stagnant zones (Rutkowski 2009b). For example, if a $4 \times 8$ supply outlet in the system was properly selected for sufficient throw and noise criteria at 500-700 ft/min face velocity when delivering $110 \mathrm{cfm}$, that same supply outlet delivering half the airflow (i.e., $55 \mathrm{cfm}$ ) falls below the manufacturer's recommended velocity range necessary for sufficient throw and spread ${ }^{3}$ to deliver room air mixing (Hart \& Cooley, Inc. 2010).

The information provided in this report can be applied to all retrofitted houses that have reduced airflow with unaltered supply air outlets, although it will be most useful in homes with floor perimeter outlets served through sheet metal ductwork that is already located within conditioned space where cooling is required. Systems using flex duct in unconditioned space are more likely to have ductwork and supply air outlets replaced during a retrofit because the ease of access and lower material costs reduce the expense of duct replacement (GreenHomes America 2013).

Therefore, houses with all-metal ducts in conditioned space with floor supply air outlets are a prime target for this study. Previous work that IBACOS completed from the 2000 U.S. Census characterized house types through a set of specifications based on the code requirements during time periods identified in cold and very cold climate zones: 31.4 million homes built prior to 1970, 14.4 million homes built from 1970 through 1989, and 7.1 million homes built from 1990 through 1999. According to the Residential Energy Consumption Survey (RECS) (EIA 2011), the respective number of homes with forced-air furnaces in cold and very cold climates is 25.3 million, as shown in Table 1.

\footnotetext{
${ }^{3}$ Spread is the width of the air stream leaving the supply outlet.
} 
Table 1. Number of Homes With Furnaces in Cold or Very Cold Climates, by Fuel Type*

\begin{tabular}{c|c}
\hline Fuel Type & $\begin{array}{c}\text { Number of Homes } \\
\text { (millions) }\end{array}$ \\
\hline Natural Gas & 20.1 \\
\hline Electricity & 1.8 \\
\hline Fuel Oil & 1.7 \\
\hline Propane & 1.7 \\
Total & 25.3 \\
\hline
\end{tabular}

* EIA (2011).

\subsection{Research Questions}

The following research questions are answered by this project:

1. What are the heating and cooling loads and the corresponding total airflow volume and room-by-room airflow volume reductions in both the pre-retrofit and post-retrofit conditions? What are the conditions of post-retrofit airflows within the pre-retrofit ducts (i.e., velocity, pressure loss, friction) based on ACCA and ASHRAE calculations?

2. In an isothermal condition, what are the face velocities, corresponding throws, and spreads of the post-retrofit airflows through the pre-retrofit size ducts and supply outlets that correspond to the reduced flows in Question 1? Do the post-retrofit airflows through the pre-retrofit size ducts and supply outlets improve terminal conditions at the supply outlets?

3. What are the potential issues with methods for a strategy to increase throw by decreasing the net free area of the diffuser? 


\section{Mathematical and Modeling Methods}

IBACOS used modeling with ACCA Manual J (Rutkowski 2006) to answer the research questions related to the reduced heating and cooling loads and the corresponding reduced total airflow volume and room-by-room airflow volume. The answers to the research question related to the conditions of post-retrofit airflows within the pre-retrofit ducts (i.e., velocity, pressure loss, friction) were based on calculations from ASHRAE Fundamentals (ASHRAE 2009).

\subsection{Load Calculation}

To determine the total loads and room-by-room airflows, IBACOS used ACCA-approved Manual J (Rutkowski 2006) load calculation software. The load calculations were performed for a two-story 1960s vintage house. Figure 1 shows the floor plan for this two-story house.
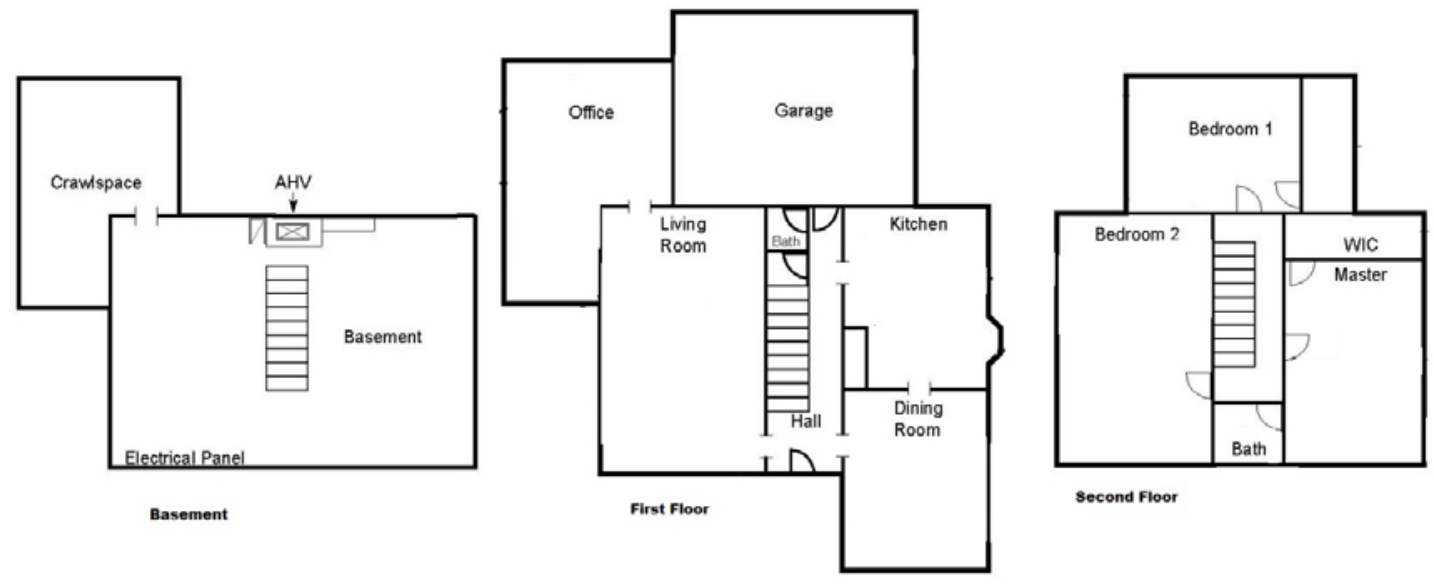

Figure 1. Two-story floor plan

Table 2 lists the energy efficiency upgrade measures for the post-retrofit condition. These are relevant to the thermal enclosure and are based on previous IBACOS work completed in a NYSERDA deep energy retrofit study (Herk et al. 2014).

Table 2. Pre- and Post-Retrofit Specifications

\begin{tabular}{c|c|c}
\hline Component & Pre-Retrofit & Post-Retrofit \\
\hline Basement Walls & Uninsulated & R-4 rigid \\
Windows & Single pane, & Double pane, \\
& U-value $=0.869$, & U-value $=0.285$, \\
SHGC $=0.619$ & SHG $=0.35$ \\
Ducts & Leaky, uninsulated, & Leaky, uninsulated, \\
in conditioned space
\end{tabular}

$\mathrm{ACH}$ is air changes per hour. SHGC is solar heat gain coefficient. 


\subsection{Duct Sizing and Layout}

To characterize the duct sizes and layout in this project, IBACOS used industry "rules of thumb" and the house characteristics recorded in the NYSERDA deep energy retrofit study by Herk et al. (2014). IBACOS performed ASHRAE Fundamentals (ASHRAE 2009) duct-sizing calculations for the unaltered ducts and the post-retrofit airflows. The team input the post-retrofit airflows into a duct design spreadsheet that used ASHRAE duct design calculations to look at airflow velocities and pressure changes with respect to friction factor, duct size, duct length, and fittings. IBACOS quantified the post-retrofit room-by-room airflows for the pre-retrofit ducts by calculating the new equipment flows through the existing ducts sizes against the ASHRAE 2009 duct-sizing calculations. This analysis was used to evaluate whether airflow delivered to each room meets the room-by-room load. 


\section{Experimental Methods}

IBACOS used a mocked-up duct and register setup to measure the characteristics of isothermal air - to reduce the effects of the buoyancy on heated or cooled air from the observationspassing through the duct and leaving the register. ${ }^{4}$

\subsection{Measurement of Face Velocity, Throw, and Spread}

Two 10-ft lengths of 6-in. round sheet metal duct with two configurations of boot were used to mock up the testing duct runs, as shown in Figure 2. Based on the industry "rules of thumb" used to characterize the duct layout for the modeling effort, the duct runs were not sealed with mastic along the seams.

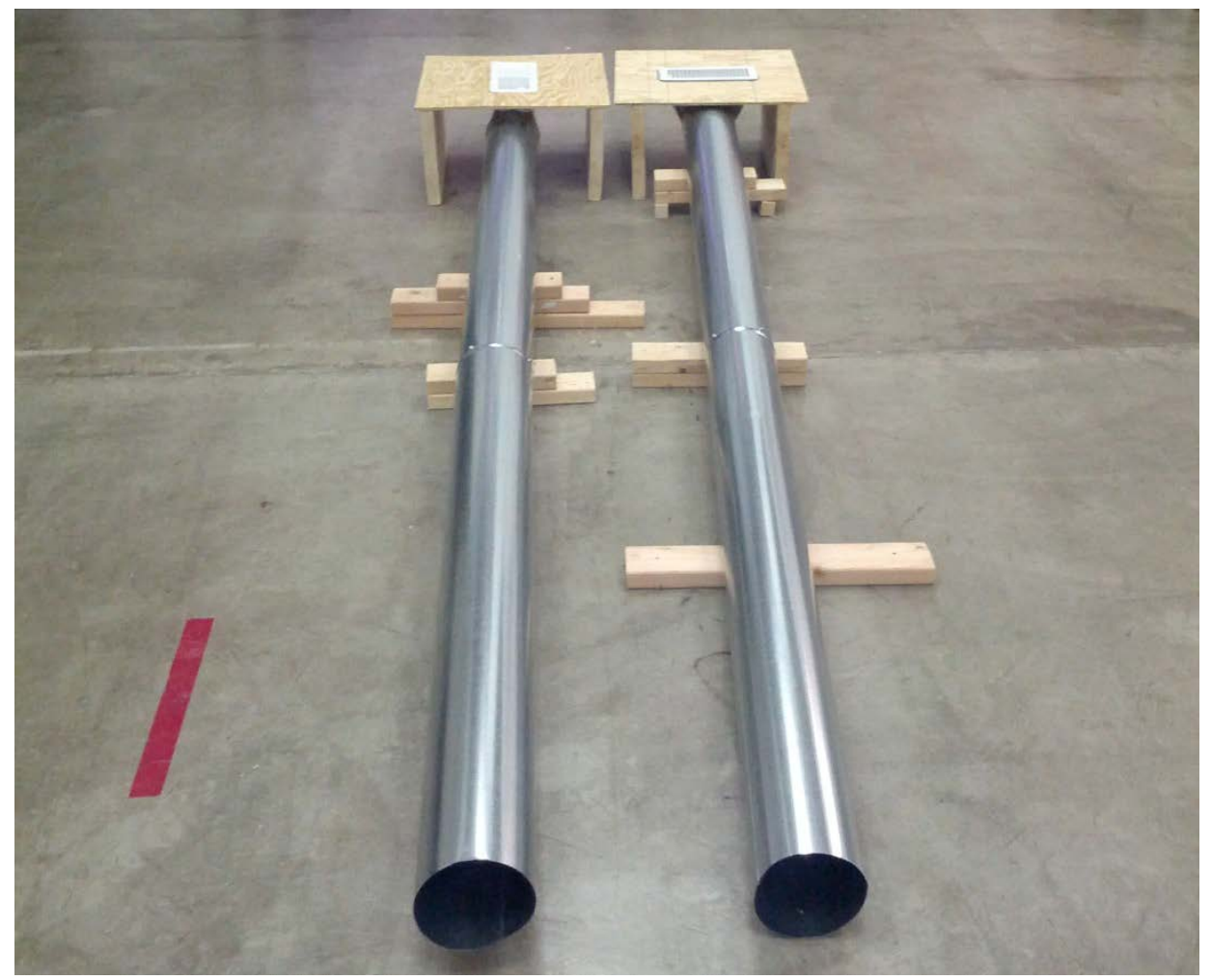

Figure 2. Mockup of the testing duct runs

The supply air outlets were $4 \times 10$ stamped steel, rectangular floor registers, indicative of those found in the NYSERDA study house (Herk et al. 2014). Two boot configurations were used: the ACCA Manual D fitting 4G boot with the long side of the register perpendicular to the duct run (Figure 3), and the ACCA Manual D fitting 4H boot with the long side of the register parallel with the duct run (Figure 4) (Rutkowski 2009a). The boots were installed in a square of plywood elevated in a simulated floor surface with floor joists.

\footnotetext{
${ }^{4}$ In an isothermal process, the temperature is constant.
} 


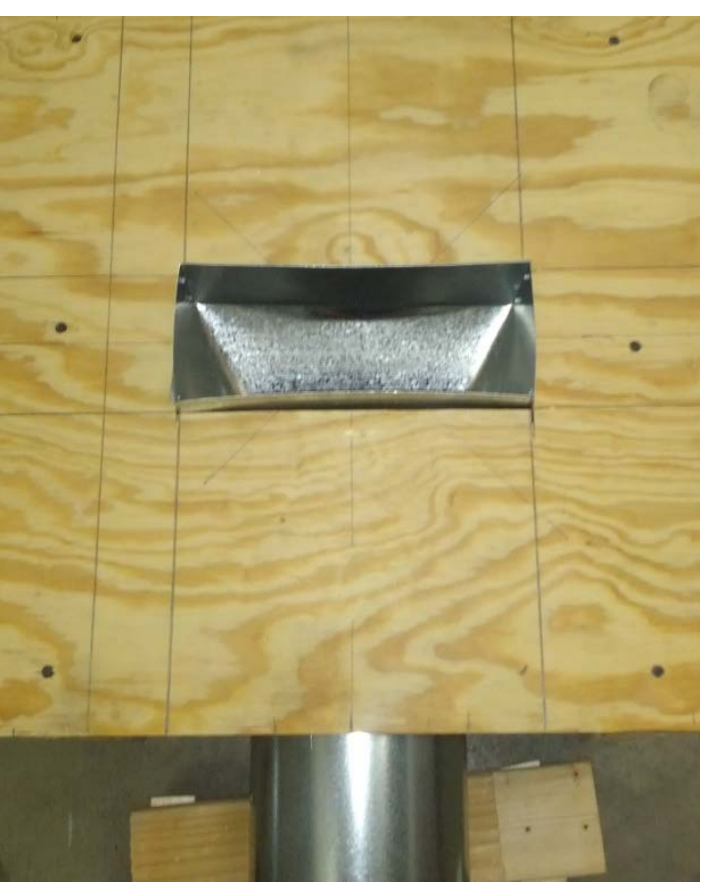

Figure 3. 4G boot configuration

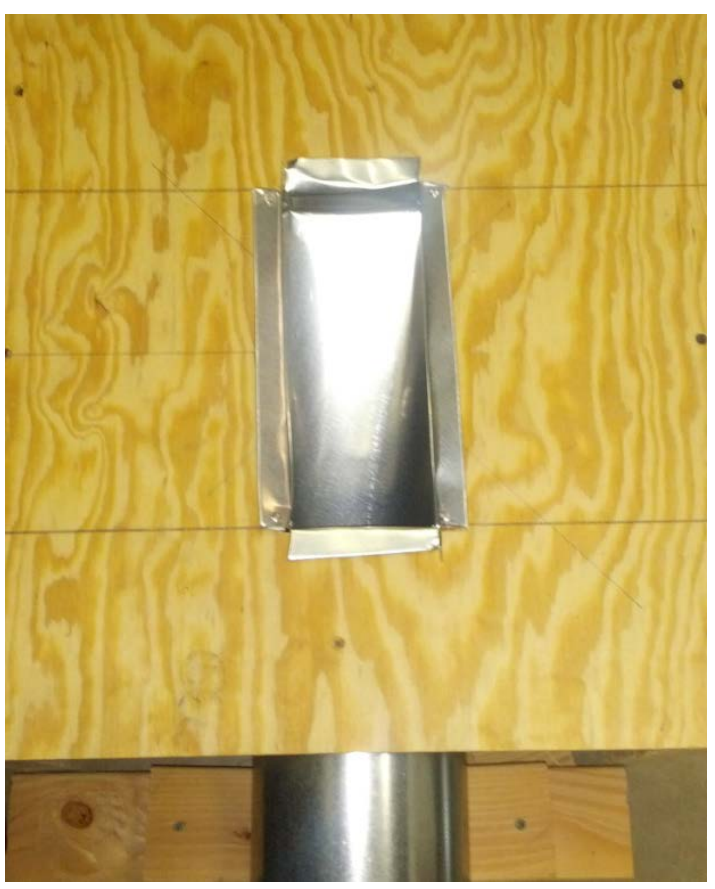

Figure 4. 4H boot configuration

IBACOS used a black backdrop with white lines drawn at 6-in. intervals to create a grid for measurements. The grid guided the measurements by placing the datum at the midpoint of the register, as shown in Figure 5.

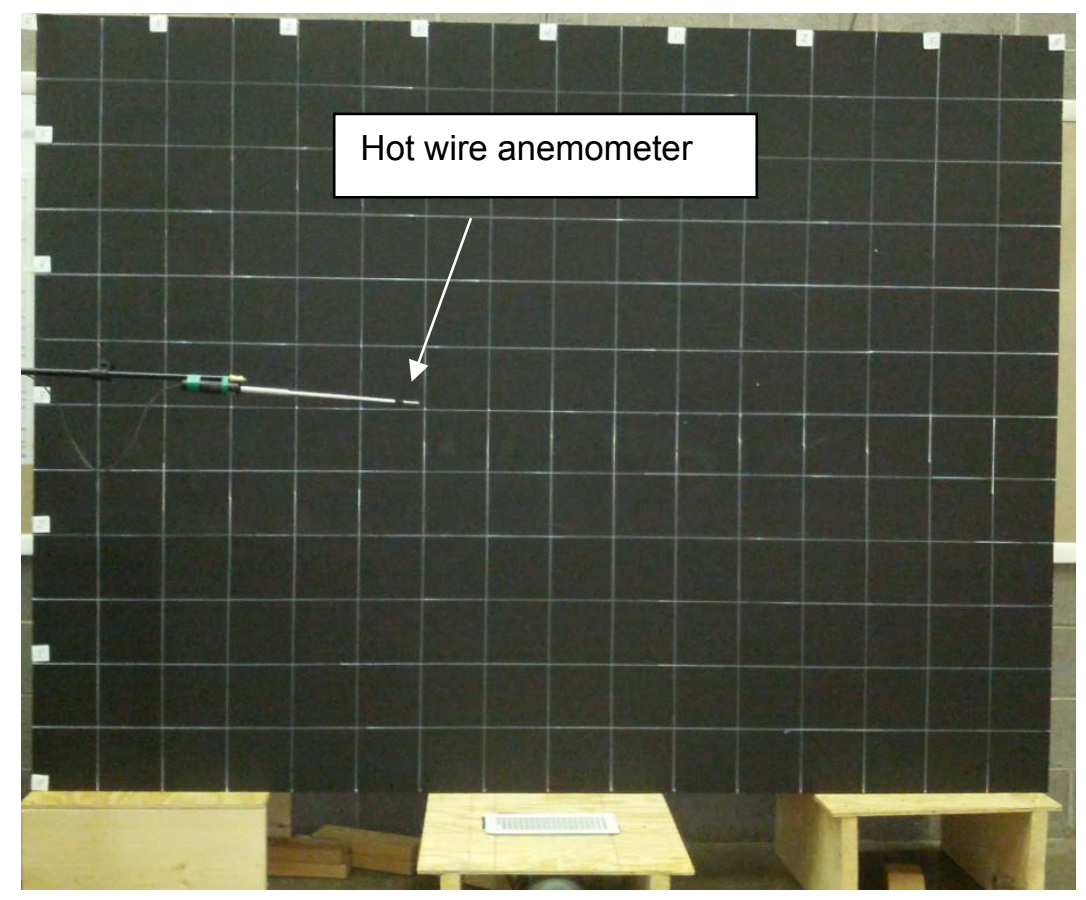

Figure 5. Measurement grid 
The team used an Energy Conservatory Duct Blaster ${ }^{5}$ to induce the isothermal airflow through the duct runs. With a manometer, it was possible to measure airflow through the Duct Blaster. Also, the team used an Energy Conservatory FlowBlaster ${ }^{6}$ capture flow hood accessory to measure airflow leaving the register. Both devices employ an Energy Conservatory DG-700 digital pressure and flow gauge. ${ }^{7}$ The accuracy of the Duct Blaster and FlowBlaster are both 3\% of the flow reading or $1 \mathrm{cfm}$, and $1 \%$ of the pressure reading or $0.15 \mathrm{~Pa}$, whichever is greater. Using $100 \mathrm{cfm}$ as the original design airflow, the flows then were reduced to $50 \mathrm{cfm}, 25 \mathrm{cfm}$, and $12 \mathrm{cfm}$ to represent $50 \%, 75 \%$, and $88 \%$ reductions in airflow, respectively.

For each flow rate, IBACOS took airflow velocity measurements at various locations for the register at $100 \%$ open area. Then $50 \%$ of the register was restricted in three configurations: $50 \%$ blocked on the half nearest to the duct, $50 \%$ blocked on the half farthest from the duct, and only the middle 50\% open. Figure 6 and Figure 7 show the $4 \mathrm{G}$ and $4 \mathrm{H}$ boot configurations, respectively, with the $4 \times 10$ register net free area reduced by $50 \%$.
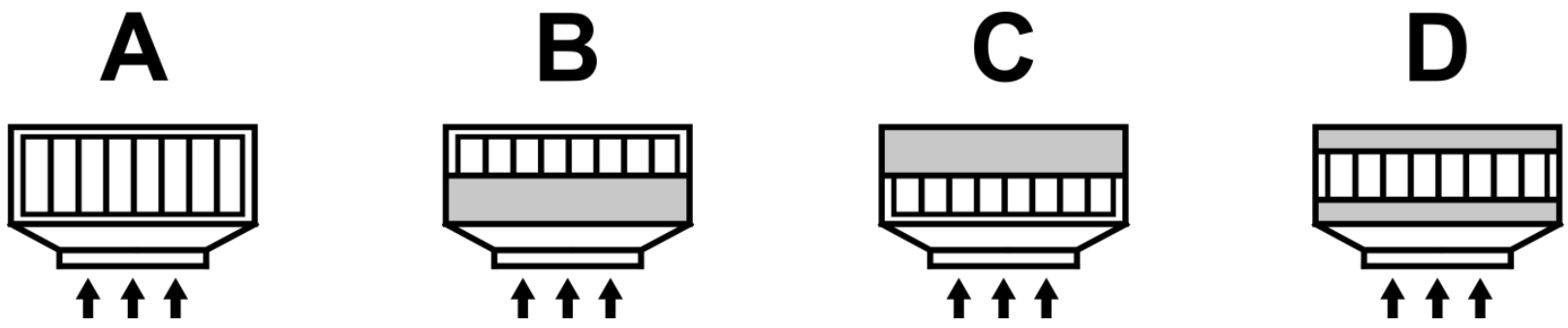

Figure 6. 4G boot configurations with the $4 \times 10$ floor register: (A) $100 \%$ open; (B) farthest from the duct, $50 \%$ open; (C) nearest to the duct, $50 \%$ open; (D) middle, $50 \%$ open
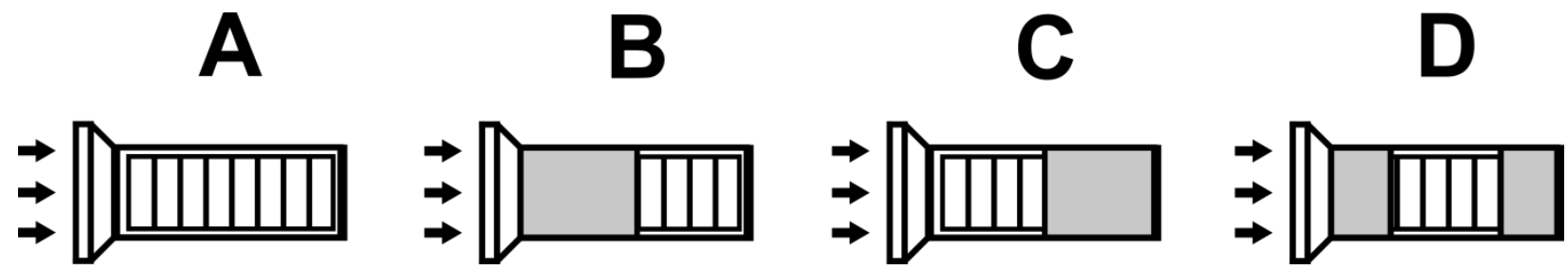

Figure 7. $4 \mathrm{H}$ boot configurations with the $4 \times 10$ floor register: (A) $100 \%$ open; (B) farthest from the duct, $\mathbf{5 0 \%}$ open; (C) nearest to the duct, $\mathbf{5 0 \%}$ open; (D) middle, $\mathbf{5 0 \%}$ open

The team initially placed a fog machine directly behind the Duct Blaster fan to visualize the changes in throw and spread when the airflow volume and blockage of the register were varied. Following the pattern identified by the fog, the areas were located on the grid where the air

\footnotetext{
${ }^{5}$ Duct Blaster. Minneapolis, MN: The Energy Conservatory. www.energyconservatory.com/products/ductblaster\% $\%$ C $\%$ AE-systems-and-accessories.

${ }^{6}$ FlowBlaster Minneapolis, MN: The Energy Conservatory. www.energyconservatory.com/products/ductblaster\%C2\%AE-systems-and-accessories/flowblaster\%C2\%AE-capture-hood-accessory.

${ }_{7}^{7}$ DG-700 digital pressure and flow gauge. Minneapolis, MN: The Energy Conservatory. www.energyconservatory.com/products/digital-pressure-gauges.
} 
reached a terminal velocity of $50 \mathrm{ft} / \mathrm{min}$ using a TSI 9555 VelociCalc hot wire anemometer. ${ }^{8}$ The device has an accuracy of $3 \%$ of the reading or $3 \mathrm{ft} / \mathrm{min}$, whichever is greater, and the accuracy statement ranges from $30 \mathrm{ft} / \mathrm{min}$ to $9,999 \mathrm{ft} / \mathrm{min}$. Because the research team was seeking $50 \mathrm{ft} / \mathrm{min}$, the team was well within the accuracy range. The velocity readings were taken at the center of the register approximately $10 \mathrm{in}$. from the grid, attempting to be in the plane with the highest velocity, or directly above the register. The test was considered complete when a perimeter defining where the design terminal velocity condition reached $50 \mathrm{ft} / \mathrm{min}$ was obtained for each airflow volume and blockage configuration.

\subsection{Measurements to Identify Potential Issues}

Decreasing the net free area of the register will increase the duct static pressure. Because the flow is reduced in the retrofit scenario due to the reduced load on the house and the new furnace, the increased static pressure may not increase duct leakage.

First, the research team measured the duct leakage (with multipoint tests) for a 10-ft-long, 6-in.diameter metal duct with an unsealed longitudinal seam. Then a 2-in.-diameter hole was drilled $2.5 \mathrm{ft}$ away from the diffuser, and the leakage was measured again.

The team completed all leakage tests using the Energy Conservatory Duct Blaster, FlowBlaster, and DG-700 manometer. Leakage rates were calculated using ASHRAE Fundamentals (2005), Section 35.14, Equation 37 for duct leakage:

$$
Q=C^{*} \Delta P_{s}^{n}
$$

where $Q$ is the leakage flow, $\Delta P_{s}$ is the difference in static pressure between the interior and exterior of the duct, and $C$ and $n$ are calculated coefficients.

Second, the research team recorded the pressure in the duct for flow rates up to $100 \mathrm{cfm}$ for both scenarios with and without the 2-in.-diameter hole in the duct. The team used a Duct Blaster to produce the airflow and a manometer to record the static pressure at the midpoint of the duct.

\footnotetext{
${ }^{8}$ TSI VelociCalc hot wire anemometer. TSI Incorporated. Shoreview, MN. www.tsi.com/velocicalc-multi-functionventilation-meter-9555/.
} 


\section{$4 \quad$ Results and Discussion}

\subsection{Reduced Load Airflow Volumes}

The results of the load calculations for the pre- and post-retrofit conditions show approximately a $65 \%$ reduction in total airflow volume. Table 3 shows the relationship between the pre- and postretrofit loads versus airflows as calculated per ACCA Manual J (Rutkowski 2006) for each space served by the forced air system. The thermal enclosure measures applied to the model reduced the overall heating and cooling loads by more than half. The heating load was reduced by $54,709 \mathrm{Btu} / \mathrm{h}$, and the cooling load was reduced by $18,719 \mathrm{Btu} / \mathrm{h}(69 \%$ and $61 \%$ reductions, respectively). Subsequently, the overall system airflow was reduced by as much as $65 \%$.

Table 3. Loads and Airflows for Pre- and Post-Retrofit

\begin{tabular}{|c|c|c|c|c|c|c|c|c|}
\hline \multirow{2}{*}{ Room } & \multicolumn{2}{|c|}{$\begin{array}{l}\text { Pre-Retrofit } \\
\text { (Btu/h) }\end{array}$} & \multicolumn{2}{|c|}{$\begin{array}{l}\text { Post-Retrofit } \\
(\text { Btu/h) }\end{array}$} & \multicolumn{2}{|c|}{$\begin{array}{l}\text { Pre-Retrofit } \\
\text { (cfm) }\end{array}$} & \multicolumn{2}{|c|}{$\begin{array}{l}\text { Post-Retrofit } \\
\text { (cfm) }\end{array}$} \\
\hline & Heating & Cooling & Heating & Cooling & Heating & Cooling & Heating & Cooling \\
\hline Den & 11,203 & 7,119 & 4,166 & 2,664 & 187 & 308 & 99 & 138 \\
\hline Living Room & 6,953 & 3,308 & 2,522 & 1,471 & 116 & 143 & 60 & 76 \\
\hline Kitchen & 4,029 & 2,729 & 1,465 & 1,678 & 67 & 118 & 35 & 87 \\
\hline Dining & 5,563 & 2,122 & 2,020 & 684 & 93 & 92 & 48 & 35 \\
\hline Bedroom 2 & 8,324 & 3,596 & 2,653 & 1,127 & 139 & 156 & 63 & 58 \\
\hline $\begin{array}{c}\text { Master Walk- } \\
\text { in Closet }\end{array}$ & 3,492 & 1,104 & 1,241 & 280 & 58 & 48 & 29 & 15 \\
\hline Bath & 1,306 & 628 & 419 & 185 & 22 & 28 & 10 & 10 \\
\hline $\begin{array}{l}\text { Master } \\
\text { Bedroom }\end{array}$ & 6,536 & 3,177 & 2,133 & 1,205 & 109 & 138 & 51 & 62 \\
\hline Bedroom 1 & 8,713 & 2,814 & 3,693 & 982 & 145 & 122 & 88 & 51 \\
\hline Basement & 23,586 & 4,079 & 4,685 & 1,187 & 393 & 177 & 111 & 61 \\
\hline Total & 79,705 & 30,588 & 24,996 & 11,870 & \multicolumn{2}{|c|}{$1,580 *$} & \multicolumn{2}{|c|}{$712 *$} \\
\hline
\end{tabular}

*Totals are based on the higher of the two flows for heating and cooling.

\subsection{Reduced Airflows Within Ducts}

The pre-retrofit duct sizes assumed were $6 \times 10$-in. rectangular sheet metal for the supply trunk, and all supply branches were assumed to be 6 -in. round sheet metal. When the post-retrofit airflows were applied to the 6-in. metal ducts used in the duct layout per industry "rules of thumb," the following characteristics of velocity and pressure were calculated.

Table 4 details the change in airflow and corresponding change in velocity for each duct run in the house. The overall reduction in airflow was $63 \%$, and reductions in diffuser face velocities ranged from $41 \%$ to $78 \%$. 
Table 4. Airflows and Velocities for Pre- and Post-Retrofit

\begin{tabular}{c|c|c|c|c|c|c|c}
\hline \multirow{2}{*}{ Room } & \multicolumn{2}{|c|}{ Pre-Retrofit } & \multicolumn{2}{c|}{ Post-Retrofit } & \multicolumn{2}{c|}{ Difference } & Difference \\
\cline { 2 - 7 } & $\begin{array}{c}\text { Flow } \\
\text { Rate } \\
\text { (cfm) }\end{array}$ & $\begin{array}{c}\text { Velocity } \\
\text { (ft/min) }\end{array}$ & $\begin{array}{c}\text { Flow } \\
\text { Rate } \\
\text { (cfm) }\end{array}$ & $\begin{array}{c}\text { Velocity } \\
\text { (ft/min) }\end{array}$ & $\begin{array}{c}\text { Flow } \\
\text { Rate } \\
\text { (cfm) }\end{array}$ & $\begin{array}{c}\text { Velocity } \\
\text { (ft/min) }\end{array}$ & $\%$ \\
\hline Den A & 103 & 525 & 37 & 188 & 66 & 337 & $64 \%$ \\
\hline Den B & 103 & 525 & 37 & 188 & 66 & 337 & $64 \%$ \\
\hline Den C & 103 & 525 & 37 & 188 & 66 & 337 & $64 \%$ \\
\hline Basement 1 & 197 & 1,003 & 43 & 219 & 154 & 784 & $78 \%$ \\
\hline Living Room A & 72 & 367 & 33 & 168 & 39 & 199 & $54 \%$ \\
\hline Living Room B & 72 & 367 & 33 & 168 & 39 & 199 & $54 \%$ \\
\hline Bining & 93 & 474 & 43 & 219 & 50 & 255 & $54 \%$ \\
\hline Kitchen A & 59 & 300 & 35 & 178 & 24 & 122 & $41 \%$ \\
\hline Kitchen B & 59 & 300 & 35 & 178 & 24 & 122 & $41 \%$ \\
\hline Bedroom 1 & 145 & 738 & 58 & 295 & 87 & 443 & $60 \%$ \\
\hline Master Walk-in & 58 & 295 & 24 & 122 & 34 & 173 & $59 \%$ \\
\hline Closet & 197 & 1,003 & 43 & 219 & 154 & 784 & $78 \%$ \\
\hline Bath & 27 & 138 & 9 & 46 & 18 & 92 & $67 \%$ \\
\hline Bedroom 2 & 156 & 795 & 58 & 295 & 98 & 500 & $63 \%$ \\
\hline Master Bedroom & 138 & 703 & 54 & 275 & 84 & 428 & $61 \%$ \\
\hline Total & 1,582 & - & 579 & - & 1003 & - & $63 \%$ \\
\hline
\end{tabular}

\subsection{Terminal Conditions}

Figure 8 shows the baseline air profiles at $50 \mathrm{ft} / \mathrm{min}$ terminal velocity of the four measured airflow volumes through an unrestricted $4 \times 10$ floor register for the $4 \mathrm{G}$ and $4 \mathrm{H}$ boot configurations. As the airflows are reduced through an unrestricted register, the throws and spreads also are reduced. For $50 \mathrm{cfm}$, the throw for both boot configurations drops to about $5 \mathrm{ft}$. For $25 \mathrm{cfm}$, the air was thrown roughly $3 \mathrm{ft}$, and at $12 \mathrm{cfm}$, there was virtually no throw. The lack of throw, spread, and air velocity at the register poses a risk to air mixing and occupant comfort. Additionally, the throw of the $4 \mathrm{H}$ boot configuration went only to one side because of the momentum of the air. 


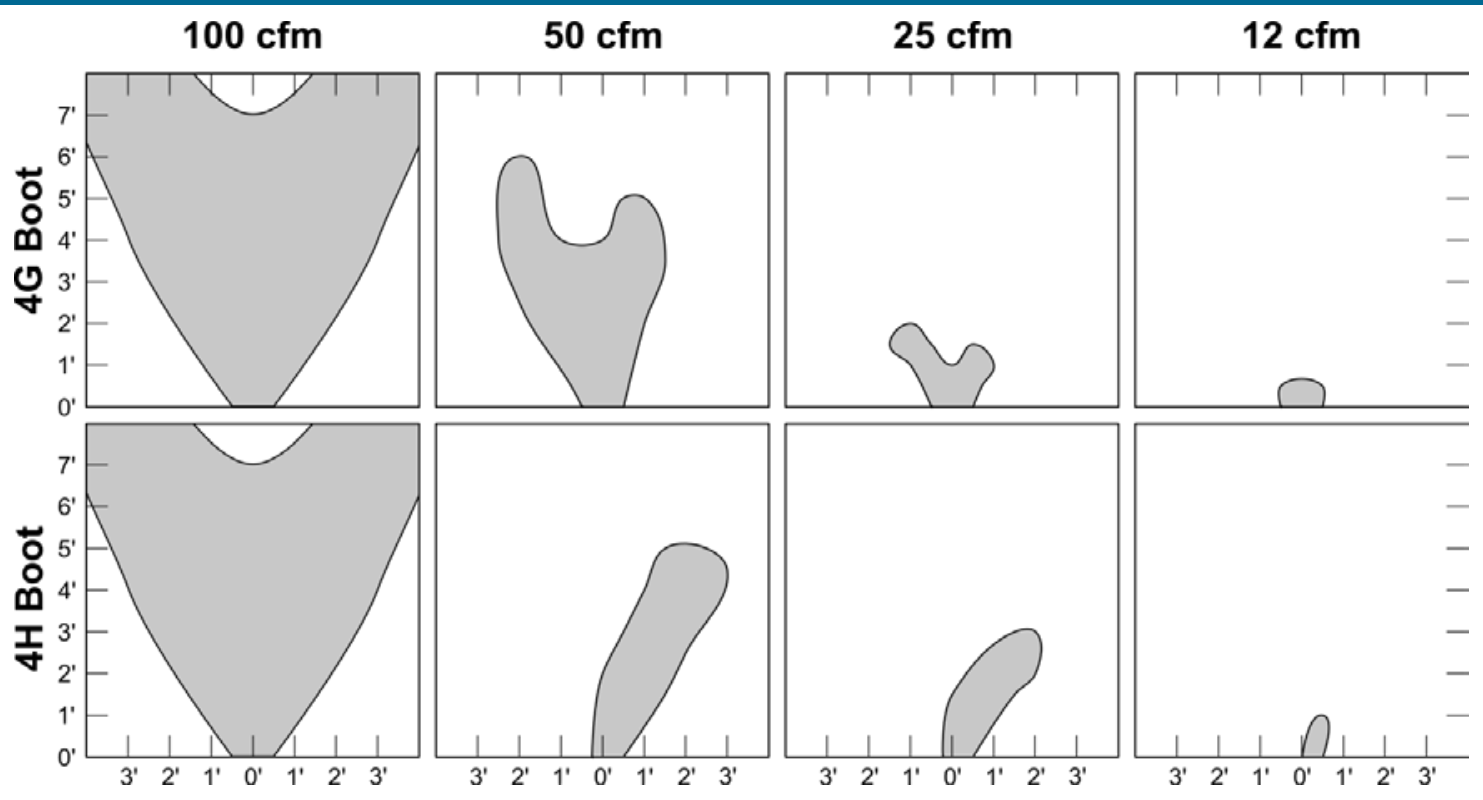

Figure 8. Air profiles of an unrestricted $4 \times 10$ floor register in two boot configurations ( $4 \mathrm{G}$ and $4 \mathrm{H}$ )

Figure 9 displays the air profiles at $50 \mathrm{ft} / \mathrm{min}$ terminal velocity of the reduced airflow volumes through a $50 \%$ restricted $4 \times 10$ floor register in the $4 \mathrm{G}$ boot configuration. When the net free area of the register was reduced by $50 \%$, the throw increased. In the $4 \mathrm{G}$ boot configuration with the half nearest to the duct restricted (B), the air was thrown toward the wall. With the $50 \%$ farthest from the duct restricted $(\mathrm{C})$, the air was thrown away from the wall.

Figure 10 displays the air profiles at $50 \mathrm{ft} / \mathrm{min}$ terminal velocity of the reduced air volumes through a $50 \%$ restricted $4 \times 10$ floor register in the $4 \mathrm{H}$ boot configuration. In all measured cases, the throw increased; however, drastic differences occurred in the direction of the throw, depending on which side was restricted. In the configuration where the half nearest to the duct was restricted (B), air was thrown farther in the same direction as in the unrestricted scenario. In the configuration where the half farthest from the duct (C) was restricted, the air was forced in the opposite direction. 
A
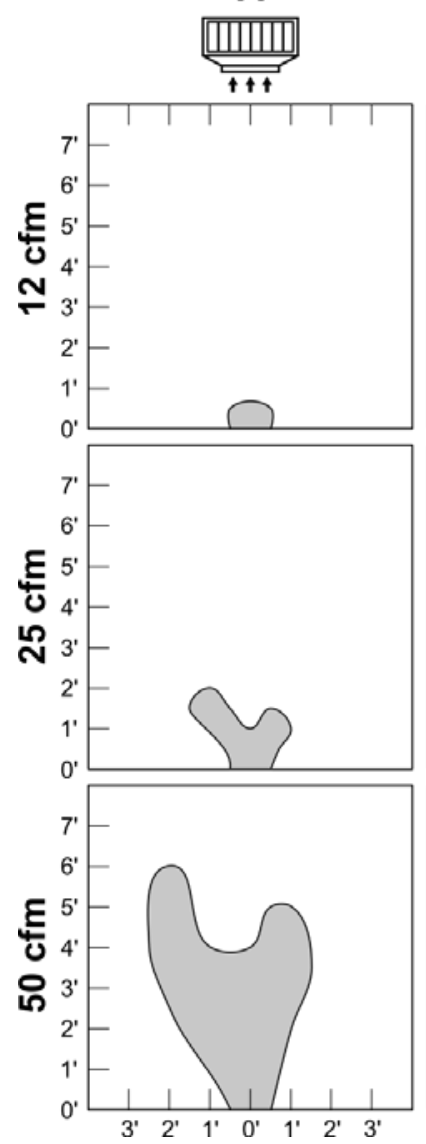

B
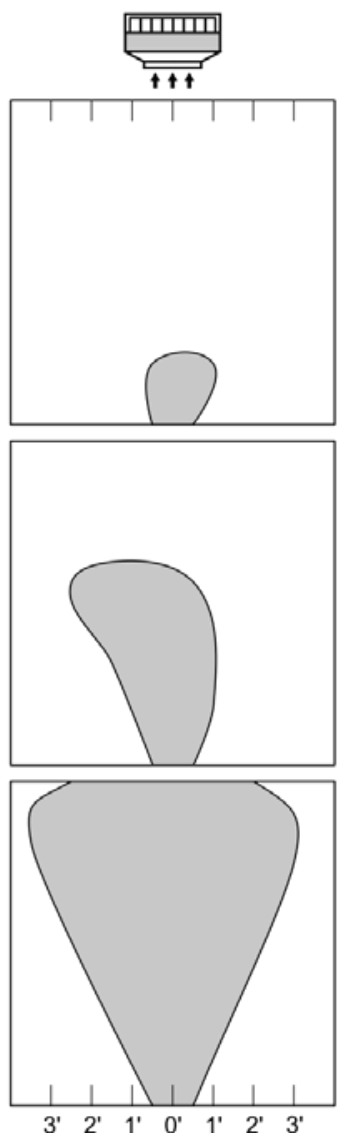

C

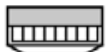

$\stackrel{t+t}{t+1}$
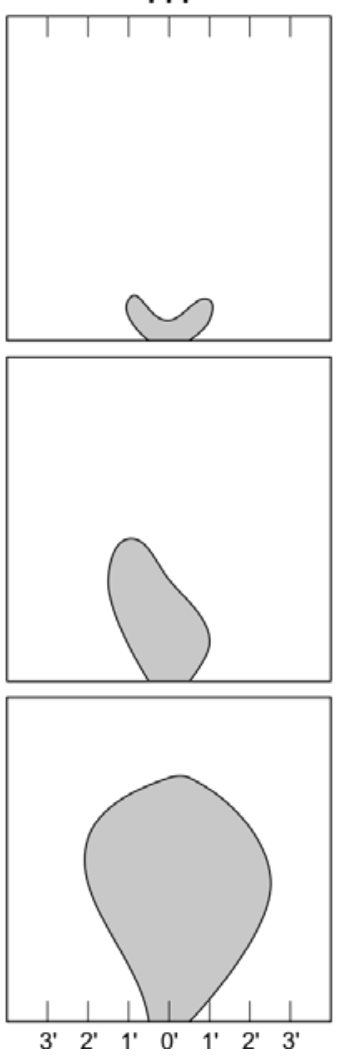

D

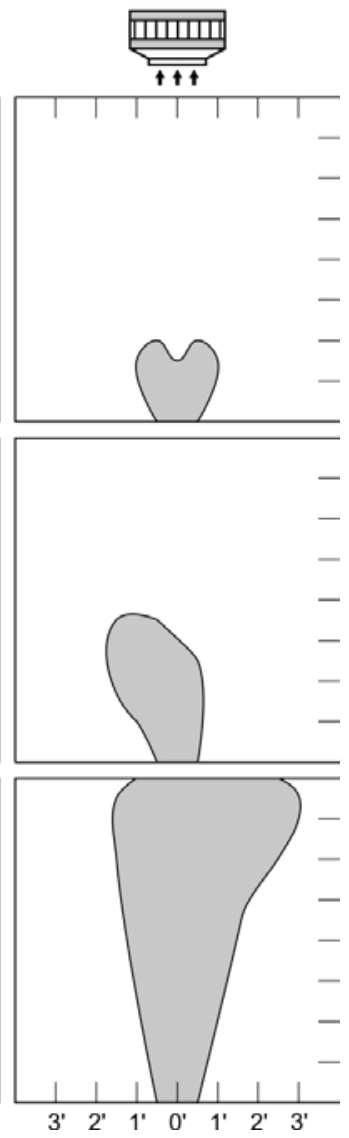

Figure 9. Reduced flow profiles through an open and restricted $4 \times 10$ register with different restriction strategies for the $\mathbf{4 G}$ boot configuration: (A) $100 \%$ open; (B) farthest from the duct, $50 \%$ open; (C) nearest to the duct, $50 \%$ open; (D) middle, $50 \%$ open 
A
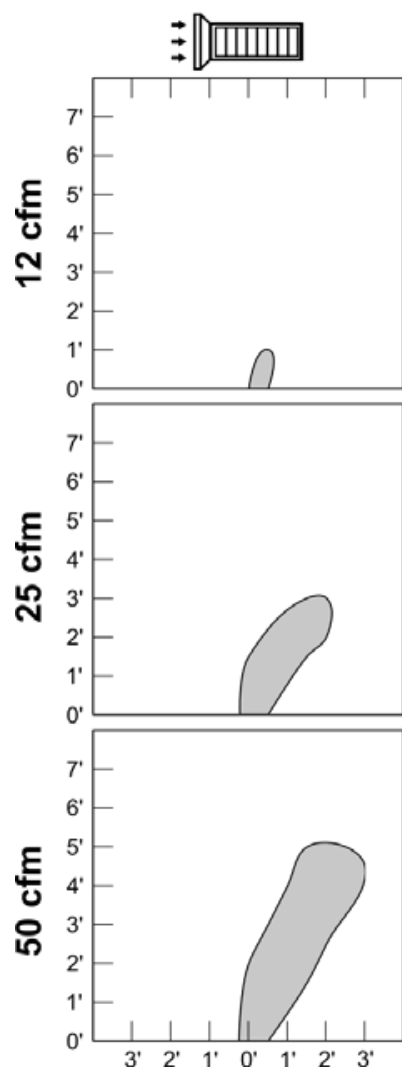

B
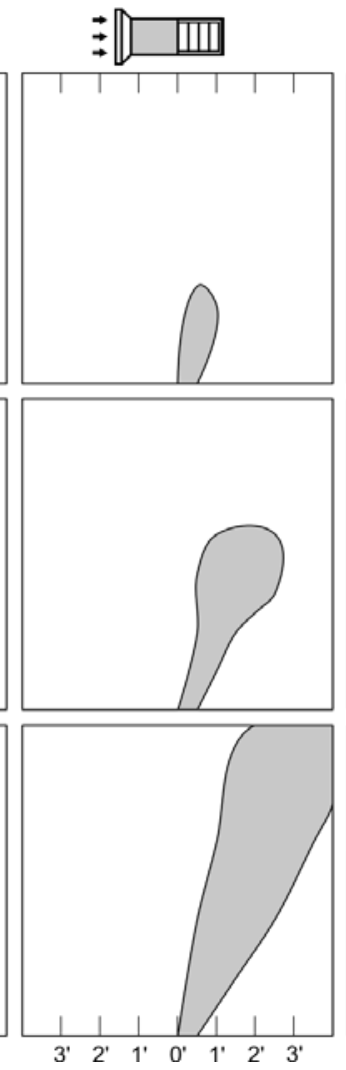

C
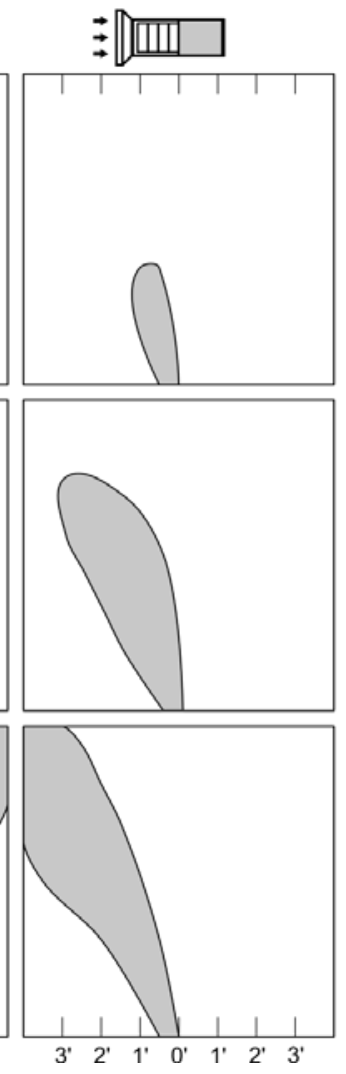

D

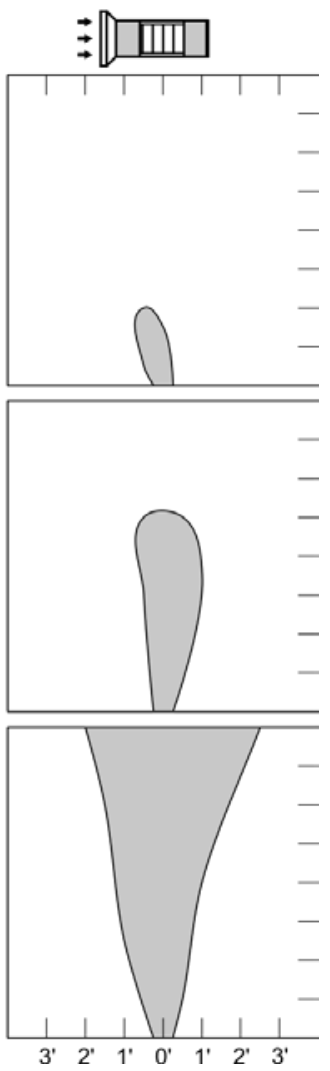

Figure 10. Reduced flow profiles through an open and restricted $4 \times 10$ register with different restriction strategies for the $\mathbf{4 H}$ boot configuration: (A) $100 \%$ open; (B) farthest from the duct, $50 \%$ open; (C) nearest to the duct, $50 \%$ open; (D) middle, $50 \%$ open

\subsection{Leakage Versus Pressure}

To investigate the impact of duct leakage for the pre- and post-retrofit scenarios where the register was restricted but the airflow was reduced, IBACOS completed two duct leakage tests as previously described. Figure 11 presents the test results.

Reading from Figure 11, the 6-in. round duct leaked $10 \mathrm{cfm}$ at $25 \mathrm{~Pa}$, whereas the same duct with a 2 -in. hole leaked $30 \mathrm{cfm}$. The increased leakage due to the 2-in. hole is approximately $20 \mathrm{cfm}$ at $25 \mathrm{~Pa}$.

The duct system was operated over a range of flow rates, and the duct static pressure was recorded for the duct without a hole and for the duct with a 2-in. hole. Figure 12 presents the results of these measurements. 
Pressure (inwg)

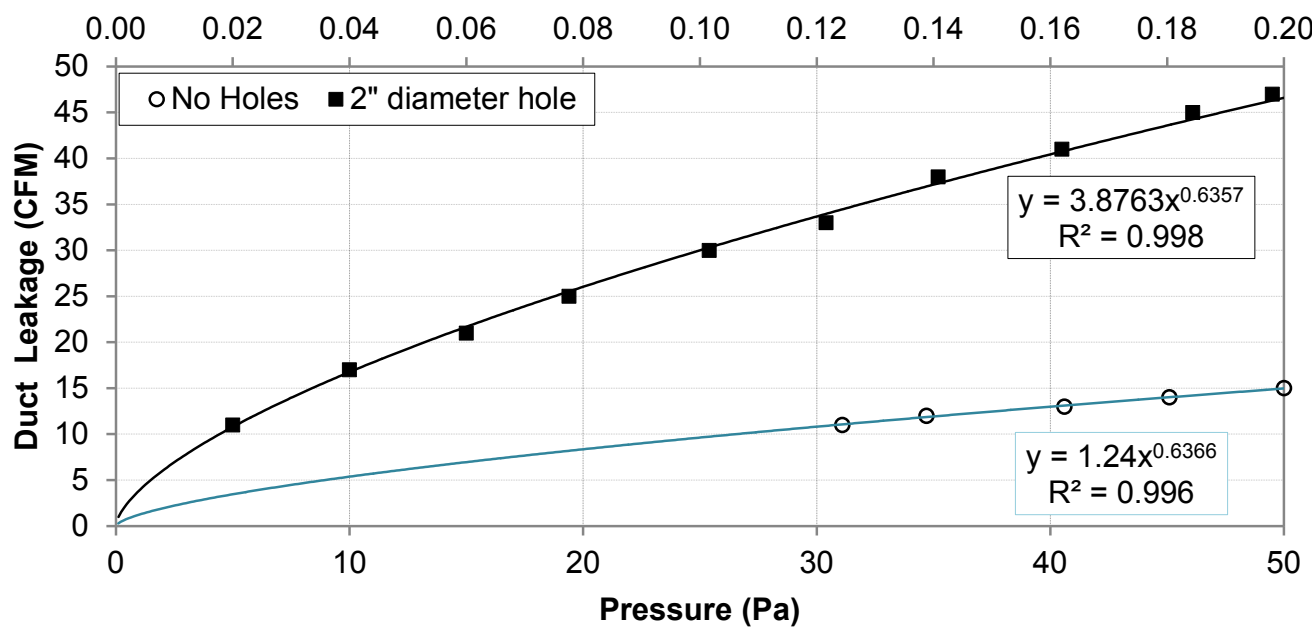

Figure 11. Duct leakage versus pressure

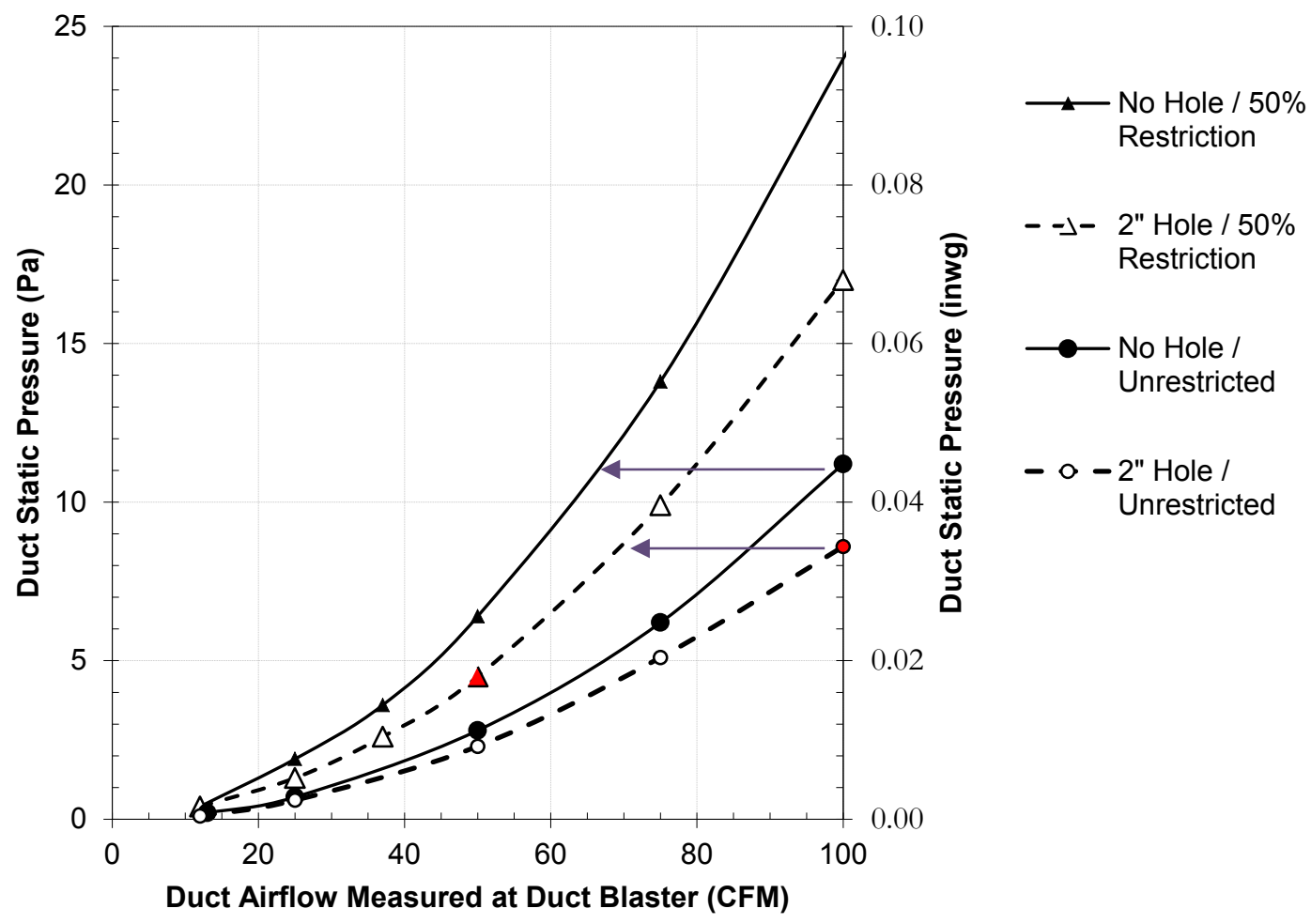

Figure 12. Duct static pressure versus duct airflow rate for different register restrictions and duct leakage 
Figure 12 indicates that the ducts with a 2-in. hole had less pressure than the ducts without a 2-in. hole. The figure also indicates that at $100 \mathrm{cfm}$, the $50 \%$ restriction resulted in an increase of $13 \mathrm{~Pa}$ for the duct with no hole; for the duct with a 2-in. hole, the restriction increased the static pressure $7 \mathrm{~Pa}$. An inference from the figure is an approximate $6 \mathrm{~Pa}$ reduction due to the 2-in. hole at $100 \mathrm{cfm}$.

The potential leakage resulting from restricting the supply register can be found using both Figure 11 and Figure 12. For example, reading from Figure 12 at $100 \mathrm{cfm}$, the duct with a 2-in. hole and no restriction has a static pressure of approximately $9 \mathrm{~Pa}$. Reading from Figure 11, the duct leakage at $9 \mathrm{~Pa}$ is $16 \mathrm{cfm}$. When the airflow in the duct system is reduced by $50 \%$ and the register opening is restricted $50 \%$, the airflow becomes $50 \mathrm{cfm}$, and the duct static pressure is 4.5 Pa. Figure 11 indicates that there is less than $5 \mathrm{cfm}$ duct leakage at this pressure. The purple arrows added to the chart in Figure 12 illustrate the end result of this analysis.

If the airflow is reduced more than $35 \%$, the static pressure will be reduced enough to reduce the duct leakage, and a larger reduction in airflow will be needed for a tighter duct system to prevent the same leakage from occurring.

The assumptions used in this analysis are specific to the duct system (duct material, hole location, register restriction, and static pressure measurement location), although the results indicate that the system leakage should be evaluated prior to restricting the registers, and the system airflow should be reduced. 


\section{Conclusions}

When a home is significantly improved with a variety of thermal enclosure measures, the peak heating and cooling loads are reduced. If the HVAC system is upgraded to better meet the loads and the duct system is not upgraded, the throw from the diffusers may not be adequate for room mixing.

This project addressed three research questions. The first question follows:

1. What are the heating and cooling loads and the corresponding total airflow volume and room-by-room airflow volume reductions in both the pre-retrofit and post-retrofit conditions? What are the conditions of post-retrofit airflows within the pre-retrofit ducts (i.e., velocity, pressure loss, friction) based on ACCA and ASHRAE calculations?

The team performed load calculations based on ACCA and ASHRAE formulas for the pre- and post-retrofit conditions, and those load calculations showed that the heating load decreased by $69 \%$, and the cooling load decreased by $61 \%$. The overall system airflow was reduced by as much as $65 \%$.

The second research question follows:

2. In an isothermal condition, what are the face velocities, corresponding throws, and spreads of the post-retrofit airflows through the pre-retrofit size ducts and supply outlets that correspond to the reduced flows in Question 1? Do the post-retrofit airflows through the pre-retrofit size ducts and supply outlets improve terminal conditions at the supply outlets?

Reduced flows through the original (now oversized) registers result in unacceptable performance of throw and spread of delivered air. By reducing the net free area of the register by $50 \%$, the team observed increases in both throws and spreads. With airflow of $50 \mathrm{cfm}$, reducing the net free area by $50 \%$ increased the face velocity to an acceptable range. The throws and spreads of the restricted register configuration improved terminal conditions at the supply outlets.

Finally, the third research question follows:

3. What are potential issues with methods for a strategy to increase throw by decreasing the net free area of the diffuser?

By adding duct restriction to the end of the supply runs, the overall static pressure of the duct is increased. The result is that all holes in the existing duct will be exposed to a higher static pressure and will leak more. Increasing the register throw by decreasing the net free area results in an increase in duct static pressure and could contribute to increased duct leakage. If the airflow is reduced by more than $35 \%$, the static pressure will be reduced enough to reduce the duct leakage, and a larger reduction in airflow is needed for a tighter duct system to prevent the same leakage from occurring. 
The assumptions used in this analysis are specific to the duct system (duct material, hole location, register restriction, and static pressure measurement location), although the results do indicate that the system leakage should be evaluated prior to restricting the registers, and the system airflow should be reduced. Installers should use their best judgment when attempting to increase the throw of conditioned air into a space. If the static pressure (and consequently the duct leakage) becomes too high, the installer should upgrade the duct system to reduce leakage. 


\section{References}

ASHRAE (2005). Fundamentals. Atlanta, GA: ASHRAE.

ASHRAE (2009). Fundamentals. Atlanta, GA: ASHRAE.

ASHRAE (2010). ANSI/ASHRAE Standard 55-2010, Thermal Environmental Conditions for Human Occupancy. Atlanta, GA: ASHRAE.

EIA (2011). Residential Energy Consumption Survey. Washington, DC: U.S. Energy Information Administration. Accessed November 10, 2014:

www.eia.gov/consumption/residential/.

GreenHomes America (2013). Personal communication; phone interview with David Abrey, Director of Quality Assurance at GreenHomes America, Inc., on June 21, 2013.

Hart \& Cooley, Inc. (2010). Residential Grilles, Registers and Diffusers, Edition 5. Grand Rapids, MI: Hart \& Cooley, Inc.

Herk, A.; Baker, R.; Prahl, D. (2014). NREL Technical Report DOE/GO-102014-4399. Spray Foam Exterior Insulation with Stand-Off Furring. Golden, CO: National Renewable Energy Laboratory.

Kampert, T.; Imm, C.; Stecher, D. (2012). Final Technical Report: Commissioning of the Round Hill, Virginia, Retrofit Unoccupied Test House. Golden, CO: National Renewable Energy Laboratory (unpublished).

Rutkowski, H. (1997). Manual RS - Comfort, Air Quality, and Efficiency by Design. Arlington, VA: Air Conditioning Contractors of America.

Rutkowski, H. (2006). Manual J-Residential Load Calculation, 8th edition, Version 2. Arlington, VA: Air Conditioning Contractors of America.

Rutkowski, H. (2009a). Manual D—Residential Duct Systems, 3rd edition, Version 1.00. Arlington, VA: Air Conditioning Contractors of America.

Rutkowski, H. (2009b). Manual T-Air Distribution Basics for Residential and Small Commercial Buildings. Arlington, VA: Air Conditioning Contractors of America.

Stecher, D.; Poerschke, A. (2014). Simplified Space Conditioning in Low-Load Homes: Results from the Fresno, California, Retrofit Unoccupied Test House. Golden, CO: National Renewable Energy Laboratory. Accessed November 10, 2014:

http://apps1.eere.energy.gov/buildings/publications/pdfs/building_america/space conditioning lowload homes.pdf.

Straub, H.E. (1956). Distribution of Air Within a Room for Year-Round Air Conditioning, Part 1. University of Illinois at Urbana Champaign, College of Engineering. Engineering Experiment Station. Accessed November 10, 2014: www.ideals.illinois.edu/handle/2142/4438.

Straub, H.E.; Chen, M.M. (1957). Distribution of Air Within a Room for Year-Round Air Conditioning, Vol. 2. University of Illinois at Urbana Champaign, College of Engineering. Engineering Experiment Station. 

Renewable Energy 